\title{
BANK LIQUIDITY AND LENDING BEHAVIOR: EVIDENCE FROM THE VIETNAMESE BANKING SYSTEM
}

\author{
Van Dan Dang* \\ Banking University of Ho Chi Minh City
}

\begin{abstract}
The study investigates the impact of liquidity on lending behavior, in the form of loan growth, at Vietnamese commercial banks for the period of 2007-2017. Notably, we also explore heterogeneous effects with the support of the generalized method of moments (GMM) for the dynamic panel data models. The robust result confirmed by alternative techniques indicates that banks with more liquidity tend to expand lending more, implying the precautionary motive of liquidity storage to finance future investments. Further analysis documents that this effect seems to be stronger for state-owned banks and mitigated in the case of banks having higher capital ratios, while we find the inconclusive results for bank size. In addition to extending the existing literature, this study provides insightful implications for bank managers and policymakers in Vietnam and other emerging economies as well.
\end{abstract}

Keywords: Bank lending; Capital; Liquidity; State Ownership; Vietnam.

Received: 12 May 2019

Accepted: 30 December 2020

https://doi.org/10.33736/ijbs.3173.2021

\section{INTRODUCTION}

Liquidity risk is considered a hazardous type of risk for bank operation, which can cause many severe impacts on the banking system, from reducing credibility to bankruptcy, even the collapse of the whole system. Besides capital management, Basel Committee on Banking Supervision (2011) emphasizes the role of liquidity, highlighting the consequences if banks do not effectively manage liquidity. As a result, banks now have to be aware of the importance of liquidity and thus actively apply strict liquidity standards, in which the newly introduced guidelines of Basel III are progressive orientations.

The initiatives of liquidity position are based on the belief that banks need enough liquid assets to maintain their intermediary role from external shocks, which can spread widely to the entire economy (Kim \& Sohn, 2017). Hence, these positions could affect a wide range of banking activities, especially the core function of banks as liquidity providers through the lending channel (DeYoung, Distinguin, \& Tarazi, 2018). Banks could tighten lending standards after a negative shock to their liquidity position, thus narrowing the credit scale provided to the economy. However, it is also believed that how liquidity influences banking behavior is uncertain (Roulet, 2018). Extending existing literature to investigate these issues empirically is not redundant in the

\footnotetext{
* Corresponding author: Banking University of Ho Chi Minh city, 36 Ton That Dam Street, Nguyen Thai Binh Ward, District 1, Ho Chi Minh City 700000, Vietnam; Tel: +84 90 3074850; Email: dandv@ buh.edu.vn.
} 
context that most of the previous studies have focused on developed countries so far (see Chen, Chou, Chang, \& Fang, 2015), instead of an emerging country like Vietnam.

Vietnam is an emerging economy with rapid economic growth accompanied by a stable political system. The banking sector dominates the financial market and dramatically contributes to the development of the economy via the bank loan supply channel. Hence, bank lending is perceived as a key indicator in Vietnam. Also, compared to banks in developed markets, banks in Vietnam (and other emerging economies as well) on average have a larger share of bank loans in total assets (Gozgor, 2014; Vo, 2018a). Interest income makes up the most dominant part of total revenue. Over the years, the pressure from increased competition forces the banking system to adjust the traditional banking activities, thereby slightly reducing the lending segments among aggregate assets (Batten \& Vo, 2019). Banks began substituting loans by other assets, which are more liquid. Thus, the share of liquid assets in the total assets of banks has likely increased.

Currently, while global banks have followed the new guidelines of Basel III, Vietnamese banks have not officially completed any version of the Basel Accords. Shortly after the global financial crisis in 2008, the Vietnamese Government approved the scheme to restructure credit institutions from 2011 to 2015, mainly focusing on the banking system, which was facing many difficulties. The restructuring plan has mentioned the goals and orientations of approaching capital standards under Basel II since 2015. Accordingly, Vietnam has had ten banks selected to complete the pilot of applying the guidelines of Basel II by 2018, before expanding to the other banks. However, only a few banks have reached the target by the end of 2018, which proves that the Vietnamese banking system currently has not approached any international standards of liquidity. Previously, to stabilize the banking market, the regulator has begun to pay attention to bank liquidity and tighten relevant regulations since 2008 (Leung, 2009). In 2014, the State Bank of Vietnam (SBV) issued the new rules regulating limits and safety ratios for credit institutions' operation, including liquidity regulations. The new regulation has introduced two ratios that require banks to comply, namely, the ratio of liquidity reserve (determined by the rate of highly liquid assets to total liabilities) and the ratio of payment ability in 30 days (similar to Liquidity Coverage Ratio (LCR) of Basel III). In general, compared to the guidelines of Basel III, the indicators of Vietnam are still "slimmer", in the spirit of the lower minimum level and domestic accounting system.

While there are a small number of studies examining the banking sector in Vietnam, the concerns of these works are typically the changes in bank efficiency and determinants of bank profitability. Some dedicated papers include Stewart, Matousek, and Nguyen (2016), Nguyen, Nghiem, Roca, and Sharma (2016), Le (2018), Batten and Vo (2019). These papers contribute to the understanding of the banking system in Vietnam by capturing the development of the sector over the last decade through multiple simple accounting measures and forward-looking indicators, then documenting the key determinants of bank performance. We are aware of two papers that deal with the bank lending behavior of the Vietnamese banks. Vo (2018a) reveals that bank loan growth significantly depends on key bank-specific and macroeconomic factors. However, the author does not take into account the heterogeneous effects across banks as well as the bank liquidity factor - the focus of our study. Dividing the banking system into private banks and state-owned banks, Sarath and Pham (2015) conclude that deposit growth significantly drives credit supply for the latter, while bank capitalization would affect bank loan growth for the latter. Like Vo (2018a), liquidity position is not the interest of Sarath and Pham (2015). 
Estimating the impact of bank liquidity, as the way the new Basel III guidelines highlight liquidity management, is necessary (Kim \& Sohn, 2017), especially in the context of an emerging country as Vietnam which is aiming to approach international standards in the future, but currently focusing mostly on capital rules. Meanwhile, authors have studied the lending behavior of banks from the standpoint of an emerging market but ignoring the role of liquidity position (see Sarath \& Pham, 2015; Vo, 2018a). These issues have motivated the study, aiming at investigating how liquidity affects the banking behavior in terms of creating more loans. Furthermore, the study also examines bank-specific factors, including bank capital, size, and state ownership, to see whether they could contribute to the heterogeneous relationship. We realize that it is necessary to allow for heterogeneity across banks. Variables capturing bank size, ownership, and capitalization (the standard bank-specific indicators employed in the former literature on bank lending) may be adequate for the accurate evaluation of banks' ability and willingness to provide more loans. Besides, the idea is also motivated by the facts that the Vietnamese banking system is currently under enormous pressure to raise capital after the period of inefficient growth (Vo, 2016), along with the domination of state-owned banks and large banks (Qian, Strahan, \& Yang, 2015). To achieve the objectives, we prioritize the dynamic approach on panel data models, by the support of the generalized method of moments (GMM) and the data set of Vietnamese commercial banks from 2007 to 2017.

The study has some contributions. First, it extends the existing literature on the importance of liquidity for lending behavior in the banking market of emerging countries. Scholars have mainly focused on developed countries due to the mature level of the banking system, the rich dataset, and the sizable fraction of bank liquid assets in total assets, which potentially alters bank lending behavior. Notably, the recent rebalancing towards reducing illiquid loans and increasing liquid assets in emerging markets has made these them ideal laboratories to perform extended analysis. In this vein, the previous studies focusing on developed countries could be confirmed as there is more evidence in different financial environments. Second, through the design of complicated heterogeneous effects by interaction terms, the study sheds light on the mechanism that the difference in bank size, capital, state ownership might affect the relationship between liquidity and lending. The unusual idea is that some banks' lending is expected to be more affected by their liquidity positions than others, so their heterogeneous actions can speak more to the effect of liquidity on bank lending. So, the consideration of heterogeneity is the key contribution of our study, given that we have made one of the first attempts to explore this strand thus far. Third, the study also introduces the liquidity reserve ratio - inspired by the regulatory criteria of Vietnamese banking, which is rarely applied by scholars to measure the liquidity position of banks. Future research could employ this ratio to offer various perspectives for their analysis. Fourth, based on robust findings, the study indicates some critical policy implications for bank managers and policymakers to strengthen liquidity strategies and regulations. This could also play a role as a reference source for other emerging countries having similar financial markets and development levels as Vietnam. Especially, it provides more insight into the hot current policy debate that the holdings of liquid assets may hamper bank lending in the sense that for a precautionary motive, banks can store liquidity to finance future investments.

The remainder of the study is structured as follows. Section 2 presents the relevant literature before developing the hypotheses. Section 3 introduces the methods, models, and data employed. Section 4 reports and discusses the research results, and finally, Section 5 concludes and points out some limitations as well as potential research directions. 


\section{LITERATURE REVIEW}

\subsection{Bank liquidity and lending behavior}

To avoid cash shortages or to timely provide potential lending in case of difficult conditions related to capital raising, banks could hold a buffer stock of liquid assets (Fama, 2013). While banks are the subject of supplying liquidity to borrowers, the loans are poorly liquid assets for banks. They could trade credits to meet liquidity requirements, but this is relatively difficult when market conditions are not favorable (Sawada, 2010). Hence, Diamond and Rajan (2001) highlight that banks tend to tighten their credit growth if the demand for future liquidity is likely to increase. In other words, it could be hypothesized that if having sufficient liquidity, especially to provide liquidity for depositors with immediacy, banks have more incentives to expand their lending.

However, there exists an alternative view on the impact of liquidity on lending, thereby forming mixed hypotheses. In terms of the balance sheet structure, banks holding many loans have tended to expand their cash buffers during the crisis (Cornett, McNutt, Strahan, \& Tehranian, 2011). In other words, to protect themselves reasonably through liquidity accumulation, banks have increased their holdings of liquid assets, while reducing investments in lending and other new credit commitments. In stress times, the more stringent liquidity requirements may force banks to cut lending, which has low productivity, high risks, and low liquidity to improve their liquidity positions by the replacement of government bonds, yielding low interest rates but risk-free (Roulet, 2018).

Many previous studies have involved monetary policy (see Chen et al., 2015) to investigate the impact of bank liquidity on lending. Altunbas, Gambacorta, and Marques-Ibanez (2009) survey European banks and suggest that banks with higher liquidity ratios would have more opportunities to grow credit faster, and more influenced by monetary policy. By the data set of Italian banks, Gambacorta (2005) previously finds that the implementation of monetary policy to tighten lending would be better for banks with less liquidity. Most recently, in another vein, the empirical research by Banerjee and Mio (2018) explores how banks respond to the more stringent liquidity regulations in the UK through Individual Liquidity Guidance (ILG), which is similar to LCR of Basel III. The authors find no evidence to prove that the application of ILG hurts bank lending in terms of loan volume.

The existing research results on how liquidity affects lending behavior are inconsistent, and mainly focusing on developed countries. Nevertheless, it is tricky to consider the banking market in an emerging country to have similar reactions in the present compared with the crisis period that Cornett et al., (2011) and Roulet (2018) analyze. Thus, we develop the following hypothesis:

\section{Hypothesis 1: Banks with more liquid assets tend to expand lending more.}

\subsection{The impact of bank capital}

Capital is an essential factor driving bank liquidity, and inconclusive flows have been found in some literature. Berger and Bouwman (2009) reveal that higher capital ratios will overwhelm deposits and reduce liquidity in small banks, but they will help to absorb risks and increase liquidity for large banks. Diamond and Rajan (2000) initially argue that equity is a buffer to protect 
depositors during the stress period, then emphasize that excessive holding of equity may reduce liquidity. In another concern, Gambacorta and Mistrulli (2004) examine lending behavior and suggest that larger capital buffers could help banks maintain the long-term lending relationships, as well as deal with the pressure of issuing new loans. In the same vein, Košak, Li, Lončarski, \& Marinč (2015) value the role of larger capital buffers in helping banks survive crises and support lending better.

We develop the hypothesis that the effect of bank liquidity on lending depends on the capital buffer, which determines the level of the upward slope. More specifically, we expect that banks with higher capital ratios tend to expand lending more after improving liquidity positions than banks with lower capital ratios. The prediction is consistent with other studies that suggest wellcapitalized banks often increase their credit aggressively (Košak et al., 2015; Louhichi \& Boujelbene, 2017).

\section{Hypothesis 2: The impact of liquidity on lending is positively correlated with bank capital.}

\subsection{The impact of bank size}

Roulet (2018) discusses the differences in business models as well as strategies for large and small banks. The author emphasizes that lending and mobilizing activities are the priority of small banks, while large banks focus mainly on trade financing and wholesale businesses. Therefore, Roulet (2018) concludes that bank size has an impact on bank liquidity positions and lending behaviors. Regarding the advantages of larger banks, Bertay, Demirgüç-Kunt, and Huizinga (2013) argue that such banks are expected to have lower cost margin and more potentials to access various funding sources in the market while still maintaining a stable loan growth. Also involving easier access to capital markets, DeYoung et al., (2018) state that this is a great chance for larger banks to adjust their funding structure more deliberately than smaller banks, and resulting in increased liquidity as a side effect. Based on these arguments, we develop the following hypothesis:

Hypothesis 3: The impact of liquidity on lending is positively correlated with bank size.

\section{$2.4 \quad$ The impact of state ownership}

Batten and Vo (2016) believe that state ownership could affect bank lending behavior, especially in emerging markets. In the same vein, Chen et al., (2015) reveal that ownership could drive risktaking behavior, typically liquidity risk. To prove this statement, Chen et al., (2015) conduct a survey on Chinese banks and reach the final conclusion that state ownership forces banks to create more liquidity, also implying that the government heavily influences state-owned banks. Then, the authors give some warnings about potential liquidity threats to the banking industry. Following these arguments, supported by the fact that state-owned banks in Vietnam are the largest banks in the system, we establish the following hypothesis:

Hypothesis 4: The impact of liquidity on lending is more pronounced for state-owned banks. 


\section{METHODOLOGY}

\subsection{Models}

Consistent with other studies on bank lending or liquidity (see Roulet, 2018), we apply a dynamic approach to appropriately capture bank behavior. Hence, we construct the baseline model as follows:

$$
\text { Lending }_{i, t}=\alpha+\beta \times \text { Lending }_{i, t-1}+\gamma \times \text { Liquidity }_{i, t-1}+\delta \times \text { Control }_{i, t-1}+\varepsilon_{i, t}
$$

where Lending $_{i, t}$ denotes lending behavior of bank $i$ at time $t$; Liquidity represents liquidity measures; Control is a vector of control variables; and $\varepsilon$ is the error term.

The dependent variable in our study, Lending, is simply measured by the rate of loan growth (Brei, Gambacorta, \& von Peter, 2013; Carlson, Shan, \& Warusawitharana, 2013; Roulet, 2018). We only examine loans for customers, not considering other types, such as interbank loans or government loans. The one-year lag of the dependent variable is also included to create a dynamic panel model.

According to the existing studies, bank liquidity is defined in many different ways, depending on the availability of data and the scholars' interests. For example, Drehmann and Gambacorta (2012) perceive cash and securities as two main items representing the liquid assets; Berrospide and Edge (2010) use the ratio of securities to total assets as a proxy for bank liquidity. In another direction, DeYoung et al., (2018) apply the rate of deposits over total loans as a traditional measure for bank liquidity. Hence, in this study we rely on the liquidity definitions of previous authors to compute the main explanatory variables, shown in the Liquidity indicator. We employ the Liquidl variable, measured by the ratio of cash and securities (as liquid assets) to total assets (Drehmann \& Gambacorta, 2012); and the $D L R$ variable, a proxy calculated by the ratio of deposits to total loans for customers (DeYoung et al., 2018). The inverse version of the $D L R$ variable is the ratio of loans to deposits commonly used by bankers to determine liquidity positions (DeYoung et al., 2018). However, to facilitate the expression of result regressions, we apply the $D L R$ alternatively.

In some countries, regulators have established liquidity standards and forced banks to meet the minimum level. Some standards are similar to LCR and the Net Stable Funding Ratio (NSFR) of Basel III (see Banerjee \& Mio, 2018). Recently, there has been another emerging research strand to apply the liquidity ratios under Basel III, besides traditional accounting measures. In Vietnam, the new liquidity rule leads to the creation of the liquidity reserve ratio, which is determined by the ratio of highly liquid assets (including cash, deposits at other banks and the SBV) to total liabilities. As a suggestion, the study continues to apply two other definitions of liquidity, which are the rate of liquidity reserve (Reserve variable) and the ratio of liquid assets (including securities, interbank loans, and interbank deposits) to total assets as Brei et al., (2013) introduce (Liquid2 variable). The expanded regression results with the latter two variables are considered as robustness checks for our study.

Other determinants of lending behavior are also included in our model as control variables, in terms of both bank-specific and macroeconomic factors. Accordingly, we have the Size variable 
representing bank size, calculated by the natural logarithm of total assets; the Capital variable indicates bank capital, measured by the ratio of total equity to total assets; the Return variable is a proxy for bank profitability, determined by the net return on total assets; the Risk variable captures bank risk, computed by the rate of loan loss provisions to total gross loans. To control the external environment, we integrate into the model two macroeconomic variables, including the annual growth rate of GDP ( $G D P$ variable) and annual inflation rate (INF variable). The alternative regression technique with these macroeconomic variables is to verify the study's robustness. We take the one-year lag of all independent variables to avoid potential endogenous problems (Kim \& Sohn, 2017; Roulet, 2018).

To investigate the heterogeneous relationships, we incorporate into Specification 1 some interaction terms to capture the effects of bank-specific factors (Bank_Specific indicator) on the relationship between liquidity and lending. As a regression technique, we create two new dummy variables to represent bank size and state ownership, sizedum and statedum variables, respectively. The sizedum variable is assigned a value of 1 for banks which have larger size than the median of the sample and 0 otherwise; the statedum variable is equal 1 in case of state-owned bank and 0 otherwise. Thus, we specify the augmented model as follows:

$$
\begin{aligned}
\text { Lending }_{i, t}= & \alpha+\beta \times \text { Lending }_{i, t-1}+\gamma \times \text { Liquidity }_{i, t-1}+\delta \times \text { Control }_{i, t-1} \\
& +\varphi \times \text { Liquidity }_{i, t-1} \times \text { Bank_Specific }_{i, t-1}+\varepsilon_{i, t}
\end{aligned}
$$

\subsection{Regression methods}

Compatible with the dynamic approach on the panel data model, we use the GMM estimators with both system GMM (S-GMM) and difference GMM (D-GMM) to deal with intrinsic endogenous problems (Arellano \& Bond, 1991; Arellano \& Bover, 1995). Combining both estimators is to validate the robustness. Moreover, the GMM estimators could overcome the problem of heteroskedasticity and autocorrelation by some corrections. To verify the appropriateness of the estimation models, we conduct further diagnostic tests, including the Hansen/Sargan related to the validity of instrumental variables and Arellano-Bond test for autocorrelation of the error term.

\subsection{Data}

The study employs data from two sources, including bank-level data on annual financial statements from the Bankscope database and Vietnam's macroeconomic data from World Development Indicators (WDI) in the period from 2007 to 2017. To obtain a suitable data set for statistical analysis, we filter data from the Bankscope database through some steps. First, due to the investigation of banking behavior and other factors associated with performance, banks suffer from substantial impacts that significantly alter their operation regime are considered to be excluded. This group consists of merged and acquired banks, and banks under special control of the SBV. Next, we remove banks failing to publish financial statements for five consecutive years. Finally, our sample has 30 commercial banks with 318 observations, including listed and unlisted ones, leading to an unbalanced panel data. 
The summary statistics presented in Table 1 show that the loan growth of Vietnamese banks in the period of 2007-2017 is very high with the annual average value of $41.83 \%$. Furthermore, the large standard deviation and the significant disparity between the extreme values of loan growth show that banks in the same system have a considerable differentiation in business strategy and competence. Meanwhile, shown by the rate of liquidity reserve, the Vietnamese banking system in general have met the liquidity requirements of regulatory agencies. The average value has dramatically exceeded the minimum level of $10 \%$ regulated by SBV from 2014. However, there are extreme values that show deficient liquidity positions.

Table 1: Summary statistics

\begin{tabular}{|c|c|c|c|c|c|c|}
\hline Variables & "Descriptions & Mean & Std. Dev. & Min & Max & Obs. \\
\hline Lending (\%) & the rate of loan growth & 41.83 & 121.04 & -99.82 & 1,654 & 318 \\
\hline Size & the logarithm of total assets & 18.00 & 1.33 & 13.70 & 20.90 & 318 \\
\hline Capital (\%) & $\begin{array}{l}\text { the ratio of total equity to total } \\
\text { assets }\end{array}$ & 11.03 & 7.64 & 3.49 & 80.83 & 318 \\
\hline Return $(\%)$ & the net return on assets & 0.83 & 0.78 & -5.51 & 5.95 & 318 \\
\hline Risk (\%) & $\begin{array}{l}\text { the ratio of loan loss provisions } \\
\text { to total loans }\end{array}$ & 1.41 & 2.46 & 0.05 & 43.96 & 318 \\
\hline $\operatorname{DLR}(\%)$ & the ratio of deposits to total loans & 118.1 & 36.65 & 6.44 & 425.3 & 318 \\
\hline Liquid1 (\%) & $\begin{array}{l}\text { the ratio of cash and securities to } \\
\text { total assets }\end{array}$ & 18.49 & 8.18 & 0.79 & 48.45 & 318 \\
\hline Liquid2 (\%) & $\begin{array}{l}\text { the ratio of cash, securities, } \\
\text { interbank lending and deposits at } \\
\text { other banks to total assets }\end{array}$ & 37.84 & 12.81 & 7.94 & 81.59 & 318 \\
\hline Reserve (\%) & $\begin{array}{l}\text { the ratio of cash, reserves held at } \\
\text { the state bank and deposits at } \\
\text { other banks to total liabilities }\end{array}$ & 21.84 & 21.11 & 1.49 & 288.2 & 318 \\
\hline $\operatorname{GDP}(\%)$ & the annual growth rate of GDP & 6.09 & 0.59 & 5.24 & 7.12 & 318 \\
\hline $\operatorname{INF}(\%)$ & the annual inflation rate & 8.46 & 6.37 & 0.87 & 23.11 & 318 \\
\hline sizedum & $\begin{array}{l}\text { equals } 1 \text { if bank size exceeds } \\
\text { median value, and } 0 \text { otherwise }\end{array}$ & 0.49 & 0.50 & 0 & 1 & 318 \\
\hline statedum & $\begin{array}{l}\text { equals } 1 \text { for state-owned bank } \\
\text { and } 0 \text { otherwise }\end{array}$ & 0.13 & 0.34 & 0 & 1 & 318 \\
\hline
\end{tabular}

We also build the correlation coefficients matrix. The results in Table 2 show that most of the correlation coefficients are small, supporting the assumption of non-existent multicollinearity. Interestingly, we could observe that the correlation coefficients of liquidity variables are not large, suggesting the robustness of research results by many alternative measures. Exceptionally, the correlation between state ownership and bank size is relatively high. This observation is consistent with the practice of the banking market in Vietnambut raising concerns about the spurious regression if these two variables attain the statistically significant results showing the same effect on lending behavior. 


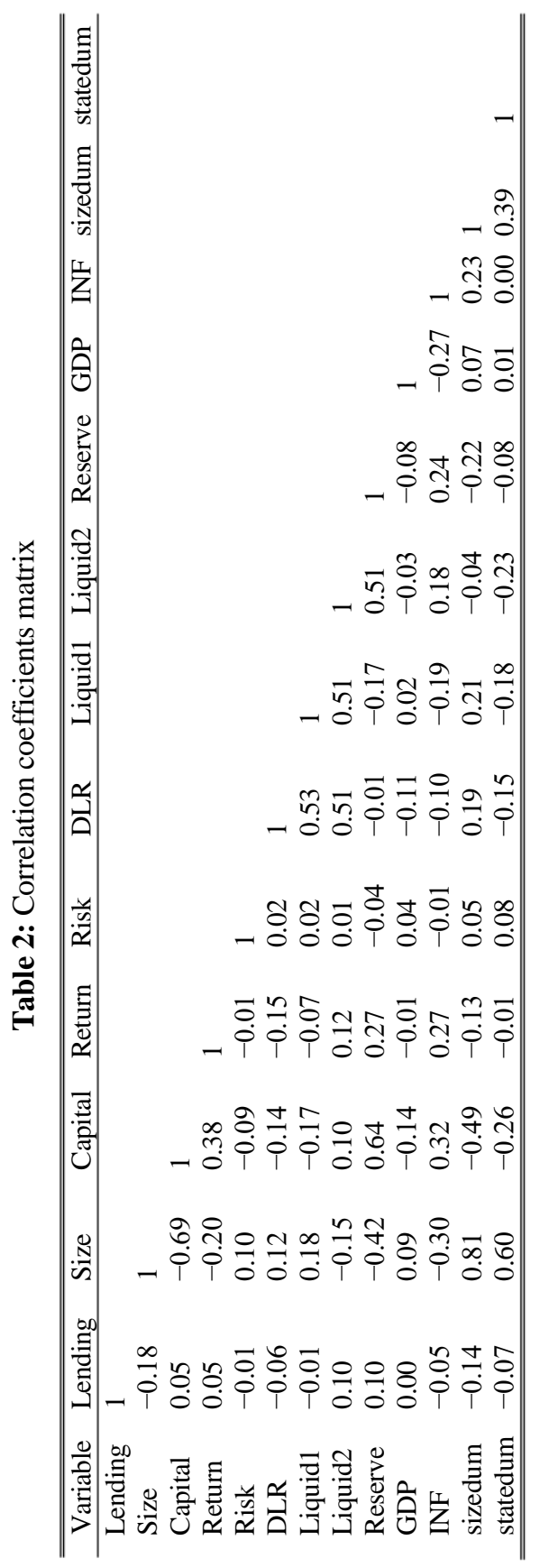




\section{RESULTS AND DISCUSSIONS}

\subsection{The effects of liquidity on bank lending — baseline model}

In Table 3, we present the regression results of Specification 1 to find out how liquidity affects lending behavior in terms of loan growth. The validation tests (Hansen/Sargan test and ArellanoBond test) show that we could rely on the regression results to conclude with acceptable reliability. Furthermore, the results indicate that lending behavior is driven by itself in the past, through a statistically significant coefficient of the lagged dependent variable. This supports the dynamic approach that we have applied to this study.

Table 3: Regression results for bank lending

\begin{tabular}{|c|c|c|c|c|}
\hline Variables & (1) S-GMM & (2) S-GMM & (3) D-GMM & (4) D-GMM \\
\hline \multirow[t]{2}{*}{ Lending $_{\mathrm{t}-1}$} & 0.043 & 0.063 & 0.042 & 0.043 \\
\hline & $(0.002)^{* * *}$ & $(0.001)^{* * *}$ & $(0.001)^{* * *}$ & $(0.002)^{* * *}$ \\
\hline \multirow[t]{2}{*}{ Liquid $1_{t-1}$} & 0.467 & & 0.336 & \\
\hline & $(0.086)^{* * *}$ & & $(0.136)^{* *}$ & \\
\hline \multirow[t]{2}{*}{$\operatorname{DLR}_{t-1}$} & & 0.844 & & 0.840 \\
\hline & & $(0.034)^{* * *}$ & & $(0.073)^{* * *}$ \\
\hline \multirow[t]{2}{*}{ Capital $_{t-1}$} & 15.775 & 15.676 & 18.295 & 17.886 \\
\hline & $(0.171)^{* * *}$ & $(0.353)^{* * *}$ & $(0.208)^{* * *}$ & $(0.301)^{* * *}$ \\
\hline \multirow[t]{2}{*}{ Size $_{t-1}$} & 32.367 & 30.556 & 16.106 & 12.539 \\
\hline & $(1.426)^{* * *}$ & $(1.793)^{* * *}$ & $(1.532)^{* * *}$ & $(1.607)^{* * *}$ \\
\hline \multirow[t]{2}{*}{ Return $_{t-1}$} & -21.283 & -18.593 & -26.560 & -23.423 \\
\hline & $(0.559)^{* * *}$ & $(1.322)^{* * *}$ & $(1.133)^{* * *}$ & $(0.884)^{* * *}$ \\
\hline \multirow[t]{2}{*}{ Risk $_{t-1}$} & -0.650 & -0.016 & -1.349 & -0.695 \\
\hline & $(0.429)$ & $(0.325)$ & $(0.354)^{* * *}$ & $(0.246)^{* * *}$ \\
\hline Observations & 288 & 288 & 258 & 258 \\
\hline \multirow[t]{2}{*}{ Serial correlation test } & -0.41 & -0.43 & 0.32 & 0.12 \\
\hline & $(0.683)$ & $(0.670)$ & $(0.742)$ & $(0.901)$ \\
\hline \multirow[t]{2}{*}{ Over-identification test } & 25.59 & 28.48 & 26.41 & 27.58 \\
\hline & $(0.999)$ & $(0.998)$ & $(0.281)$ & $(0.231)$ \\
\hline
\end{tabular}

Notes: This table reports the regression results of Specification 1 by S-GMM (columns 1 and 2) and D-GMM (columns 3 and 4) estimators. The dependent variable is bank lending, measured by the rate of loan growth. To check overidentifying restrictions, we conduct the Sargan/Hansen test (showing the value of Z-test and Prob > Z); to examine the second-order autocorrelation, we apply the Arellano-Bond test (showing the value of $\chi^{2}$ test and Prob $>\chi^{2}$ ). Symbols $*$, $* *$, and $* * *$ indicate statistical significance at the $10 \%, 5 \%$, and $1 \%$ levels, respectively.

We begin with liquidity measures by Liquid1 and DLR in the regressions using both the S-GMM and D-GMM estimators. All results show the statistically significant positive correlation between liquidity and lending at the level of $1 \%$. This indicates that more liquid banks tend to expand their lending more. The finding is consistent with most previous arguments and supports Hypothesis 1 . The rational explanation is that when banks hold more liquid assets, they could be assured of the requirement to increase liquidity in the future and thus they are able to expand lending more in the short term (Diamond \& Rajan, 2001), as well as be ready to meet the business plans associated with loans proactively (Fama, 2013). The limited approach to the second version of the Basel Accords has made Vietnamese banks partially ignore the importance of liquidity. Hence, this 
finding provides important policy implications for bank managers and regulatory agencies to pay more attention to this management aspect.

The results presented in Table 3 also show the significant impacts of other bank-specific factors. Similar to previous findings (see Distinguin, Roulet, \& Tarazi, 2013; Košak et al., 2015), we gain evidence that bank capital is an essential foundation to motivate credit growth, through a positive association found. This finding reasonably explains why the regulatory authorities in Vietnam are particularly interested and highly value the role of capital for the banking system. Meanwhile, with certain advantages in accessing various funding sources, large banks tend to have more incentives to expand their business (Bertay et al., 2013). Besides explainable findings related to cautious views and monitoring motivation on the negative impact of bank risk on loan growth (Roulet, 2018), we also have an interesting conclusion about how bank profit negatively correlates with lending behavior. After achieving the desired achievements, shareholders may not demand more in the risky business strategies.

\subsection{The interaction effects of bank-specific factors and liquidity on bank lending —extended model}

To examine the heterogeneous effects in the liquidity/lending nexus, we include some interaction terms between bank-specific factors and liquidity. We could discuss the research results in Table 4 after conducting and passing the necessary tests. Notably, the regression coefficients of the control variables remain unchanged when we extend the model. This result reinforces the robustness of our study.

Some of the bank-level characteristics could drive the effect of liquidity on lending behavior. This argument is supported as the estimation results in Table 4 indicate that the regression coefficients of interaction terms are statistically significant. More precisely, at the significance level of $1 \%$, the interaction term between bank capital and liquidity is negatively correlated with loan growth, while the interaction term of state ownership exerts a positive effect. Thus, these findings support Hypothesis 4, but contrasting to Hypothesis 2. Meanwhile, although being statistically significant, the interaction term of bank size and liquidity indicates mixed results; hence Hypothesis 3 is not confirmed. Overall, we have found heterogeneous effects when considering the role of bank capital and state ownership, but the evidence is inconclusive for bank size.

As a buffer to help banks overcome major shocks in crisis times (Distinguin et al., 2013) and respond to regulatory requirements (Louhichi \& Boujelbene, 2017), bank capital is also known as a motivation to reduce agency problem for banks (VanHoose, 2007). From the perspective of riskiness from rapid lending growth (Dang, 2019), bank shareholders with more capital invested have a reason to become more cautious, even if their banks' liquidity position is improved. Hence, bank capital mitigates the impact of liquidity on bank lending. The weakened positive effect of liquidity on lending when banks increase their capital holdings provides necessary implications related to the practical application of Basel III guidelines, which introduces the liquidity standard for the first time, besides the available capital rule. We could consider the finding as a supplement to the study of Kim and Sohn (2017) on the interaction of liquidity and capital on lending behavior, from the perspective of an emerging country. 


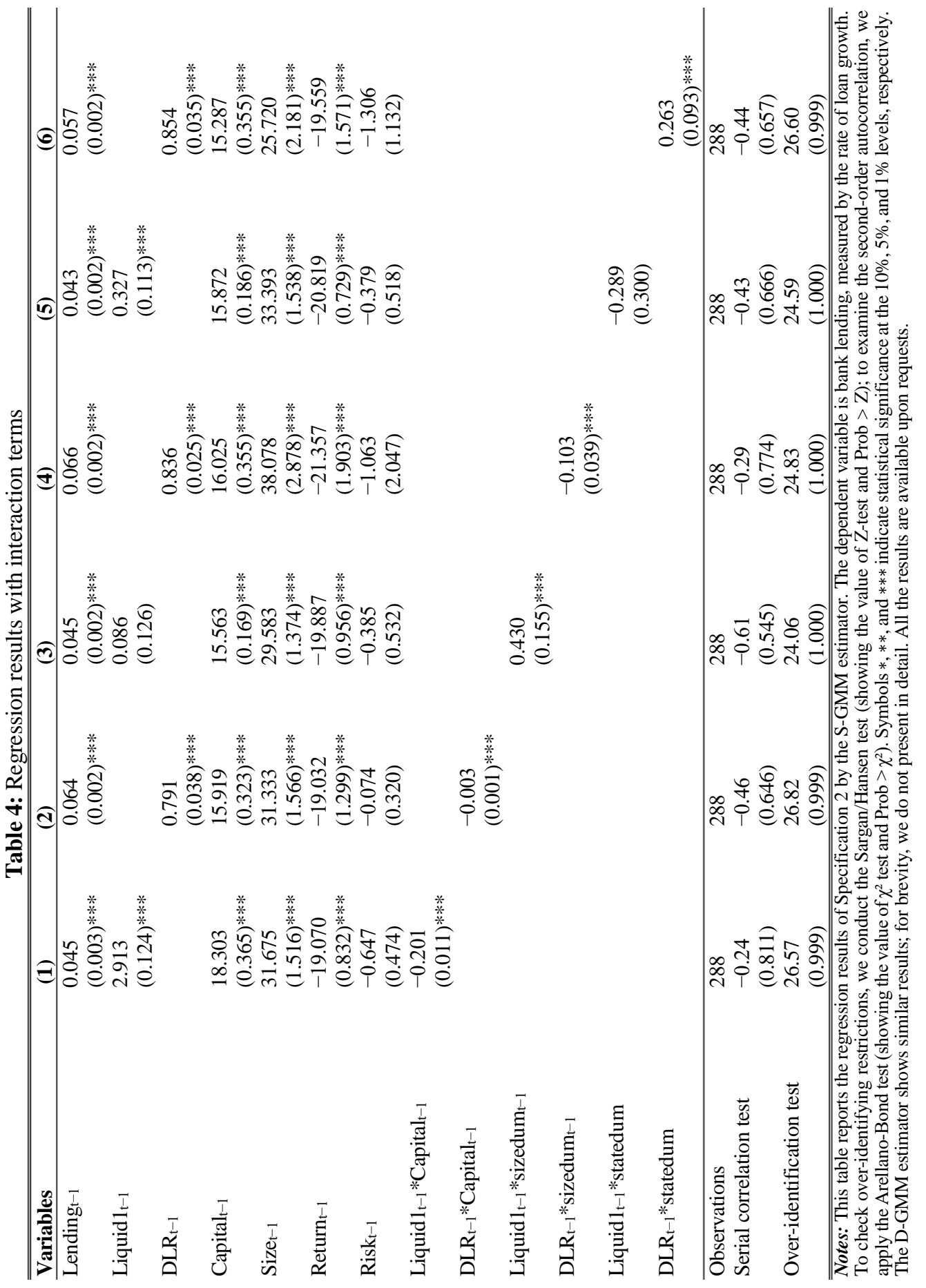


The asymmetric approach also reveals that the effect of liquidity on lending exerts an upward slope, depending on the state ownership of banks. State funding has been a prominent feature of the Vietnamese business community in recent years. Although the government has had great efforts to divest its involvement in enterprises, this process has not occurred as expectations. In this regard, many state-owned firms are still dominated by the government. These firms tend to be more reckless in terms of orientations and strategies (Vo, 2018b). Our finding adds to the conclusion of Vo (2018b) about the behaviors of non-financial enterprises in Vietnam, from the perspective of financial firms. Similar to the argument of Chen et al., (2015), the state-owned banks in an emerging country are often affected by the government, which could create more risks for the banking system. Specifically, in this case, state-owned banks tend to take more advantages of the buffer stock of liquid assets to expand lending more. Moreover, we have evidence to explain that the banking behavior in Vietnam is governed by the state ownership, rather than bank size. This doubt derives from the tight correlation between these two factors.

An implication of the classification by capital buffer or state ownership of banks may be useful for the regulatory authorities to consider regulations on liquidity management (in fact, current regulations in Vietnam focus on different bank groups, namely, commercial banks, foreign bank branches, non-bank credit institutions or cooperative banks).

\subsection{Robustness checks}

To check the robustness of previous estimation results, we use alternative independent variables and extend the regression models with macroeconomic variables. By doing so, we expect that our findings are not sensitive to the choice of the liquidity measure and the modified sets of control variables with and without macro environment. The results remain unchanged (see Table 5), thus reinforcing our previous findings and arguments.

The liquidity reserve ratio is regulated by the Vietnamese authority to assure the payment claims that are due or unexpectedly arising. Despite the non-similarity of the liquidity guidelines introduced in Basel III, this indicator shows specific impacts on bank behavior, in terms of loan growth. This finding offers the implication that in the time of preparing for Basel III, policymakers in Vietnam could expect an alternative application of liquidity reserve ratio, in terms of driving lending behavior as the study has investigated.

Turning to macroeconomic factors, we find evidence to support the procyclicality of bank lending through a positive correlation between economic growth and loan growth (Kim \& Sohn, 2017). Meanwhile, consistent with Louhichi and Boujelbene (2017), the positive impact of inflation and lending could be explained based on the low-inflation economy that will make the motivation for growth weak. In this context, banks will have difficulty expanding their financing activities. 


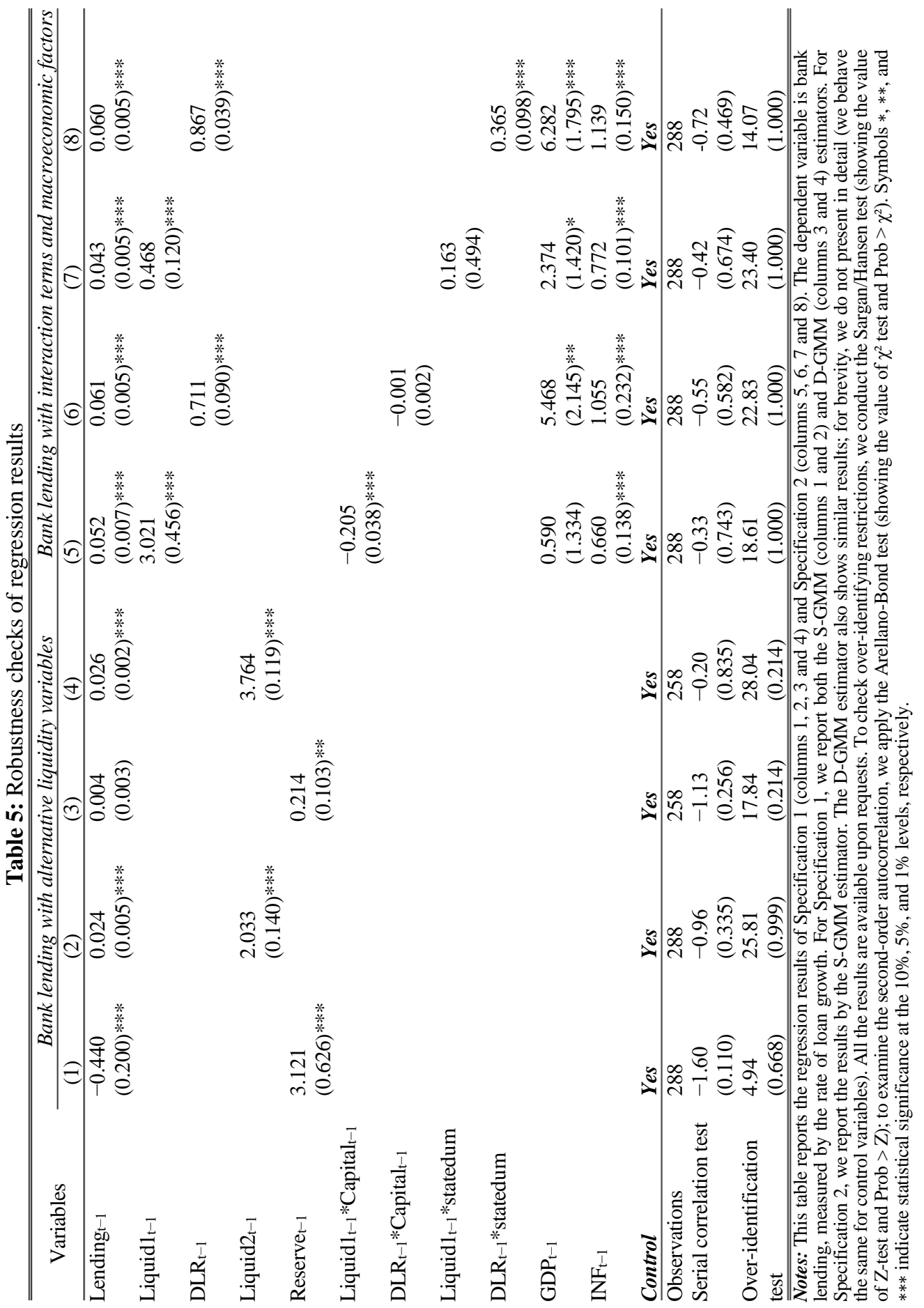




\section{CONCLUSIONS}

In this study, we examine how bank liquidity drives lending behavior, in terms of loan growth at commercial banks in Vietnam, an emerging country, through the data set from 2007 to 2017. Additionally, we also consider the heterogeneous effects, using the GMM estimators for dynamic panel data models. The findings show that bank liquidity has a positive impact on lending behavior, supporting the importance of improving the buffer stock of liquid assets to develop core banking operations. The effect seems to be stronger for state-owned banks but mitigated in the case of banks with higher capital ratios. This finding is indicated by the evidence of interaction terms integrated into our extended models. All research results are robust to replacing the dependent variables or controlling macroeconomic factors.

The study has some insightful implications. First, bank managers and policymakers need to accurately assess the importance of bank liquidity, serving the purpose of growth strategies or state management of credit limits. Giving the finding that state ownership and capital tend to make banks more sensitive to the impact of liquidity on bank lending, we call for specific policy provisions on liquidity for each different bank group. Besides, the evidence of the liquidity reserve ratio reinforces the assumptions about the meaning and non-redundant nature of the legal framework issued for banks in Vietnam.

Banks could use different methods to gauge liquidity positions, following the guidelines of new global standards under Basel III or traditional accounting measures as our study, which partially neglects the detailed quality of the liquidity buffer. As the Vietnamese banking system has not officially approached Basel III, our selection of liquidity ratios is limited and inaccessible to data on NSFR and LCR. Also, the separation of total customer loans by terms (such as short, medium, and long term) could determine the sensitivity of each group to the liquidity requirement. Furthermore, instead of focusing on each bank's liquidity position to investigate their behavior, the liquidity of the entire banking market is also an essential factor to be considered. These are some suggestions for future potential research.

\section{ACKNOWLEDGMENT}

We would like to thank the editor, Evan Lau, for handling the manuscript and the anonymous reviewers for their constructive comments and suggestions that considerably improved the quality of the manuscript.

\section{REFERENCES}

Altunbas, Y., Gambacorta, L., \& Marques-Ibanez, D. (2009). Securitisation and the bank lending channel. European Economic Review, 53(8), 996-1009.

Arellano, M., \& Bond, S. (1991). Some tests of specification for panel data: Monte-Carlo evidence and an application to employment equations. The Review of Economic Studies, 58(2), 277-297.

Arellano, M., \& Bover, O. (1995). Another look at the instrumental variable estimation of errorcomponents models. Journal of Econometrics, 68(1), 29-51. 
Banerjee, R. N., \& Mio, H. (2018). The impact of liquidity regulation on banks. Journal of Financial Intermediation, 35, 30-44.

Basel Committee on Banking Supervision. (2011). Basel III: A Global Regulatory Framework for More Resilient Banks and Banking Systems. Bank for International Settlements (BIS) publications.

Batten, J. A., \& Vo, X. V. (2016). Bank risk shifting and diversification in an emerging market. Risk Management, 18(4), 217-235.

Batten, J., \& Vo, X. V. (2019). Determinants of bank profitability - Evidence from Vietnam. Emerging Markets Finance and Trade, 55(6), 1417-1428.

Berger, A. N., \& Bouwman, C. H. S. (2009). Bank liquidity creation. Review of Financial Studies, 22(9), 3779-3837.

Berrospide, J. M., \& Edge, R. M. (2010). The effects of bank capital on lending: what do we know, and what does it mean? International Journal of Central Banking, 6(4), 5-54.

Bertay, A. C., Demirgüç-Kunt, A., \& Huizinga, H. (2013). Do we need big banks? Evidence on performance, strategy and market discipline. Journal of Financial Intermediation, 22(4), $532-558$.

Brei, M., Gambacorta, L., \& von Peter, G. (2013). Rescue packages and bank lending. Journal of Banking \& Finance, 37(2), 490-505.

Carlson, M., Shan, H., \& Warusawitharana, M. (2013). Capital ratios and bank lending: A matched bank approach. Journal of Financial Intermediation, 22(4), 663-687.

Chen, T. -H., Chou, H.-H, Chang, Y., \& Fang, H. (2015). The effect of excess lending on bank liquidity: Evidence from China. International Review of Economics and Finance, 36, 5468.

Cornett, M. M., McNutt, J. J., Strahan, P. E., \& Tehranian, H. (2011). Liquidity risk management and credit supply in the financial crisis. Journal of Financial Economics, 101(2), 297312.

Dang, V. D. (2019). The effects of loan growth on bank performance: Evidence from Vietnam. Management Science Letters, 9(6), 899-910.

DeYoung, R., Distinguin, I., \& Tarazi, A. (2018). The joint regulation of bank liquidity and bank capital. Journal of Financial Intermediation, 34, 32-46.

Diamond, D. W., \& Rajan, R. G. (2000). A theory of bank capital. Journal of Finance, 55(6), 2431-2465.

Diamond, D. W., \& Rajan, R. G. (2001). Liquidity risk, liquidity creation, and financial fragility: A theory of banking. Journal of Political Economy, 109(2), 287-327.

Distinguin, I., Roulet, C., \& Tarazi, A. (2013). Bank regulatory capital and liquidity: Evidence from US and European publicly traded banks. Journal of Banking \& Finance, 37(9), 3295-3317.

Drehmann, M., \& Gambacorta, L. (2012). The effects of countercyclical capital buffers on bank lending. Applied Economics Letters, 19(7), 603-608.

Fama, E. F. (2013). Was there ever a lending channel? European Financial Management, 19(5), 837-851.

Gambacorta, L. (2005). Inside the bank lending channel. European Economic Review, 49(7), 1737-1759.

Gambacorta, L., \& Mistrulli, P. E. (2004). Does bank capital affect lending behavior? Journal of Financial Intermediation, 13(4), 436-457.

Gozgor, G. (2014). Determinants of domestic credit levels in emerging markets: The role of external factors. Emerging Markets Review, 18, 1-18. 
Kim, D., \& Sohn, W. (2017). The effect of bank capital on lending: Does liquidity matter? Journal of Banking \& Finance, 77, 95-107.

Košak, M., Li, S., Lončarski, I., \& Marinč, M. (2015). Quality of bank capital and bank lending behavior during the global financial crisis. International Review of Financial Analysis, 37, 168-183.

Le, T. D. (2018). Bank risk, capitalisation and technical efficiency in the Vietnamese banking system. Australasian Accounting, Business and Finance Journal, 12(3), 41-61.

Leung, S. (2009). Banking and financial sector reforms in Vietnam. ASEAN Economic Bulletin, 26(1), 44-57.

Louhichi, A., \& Boujelbene, Y. (2017). Bank capital, lending and financing behaviour of dual banking systems. Journal of Multinational Financial Management, 41, 61-79.

Nguyen, T. P. T., Nghiem, S. H., Roca, E., \& Sharma, P. (2016). Bank reforms and efficiency in Vietnamese banks: evidence based on SFA and DEA. Applied Economics, 48(30), 2822 2835.

Qian, J., Strahan, P. E., \& Yang, Z. (2015). The impact of incentives and communication costs on information production and use: Evidence from bank lending. Journal of Finance, 70(4) $1457-1493$.

Roulet, C. (2018). Basel III: Effects of capital and liquidity regulations on European bank lending. Journal of Economics and Business, 95, 26-46.

Sarath, D., \& Pham, V. D. (2015). The determinants of Vietnamese banks' lending behavior. Journal of Economic Studies, 42(5), 861-877.

Sawada, M. (2010). Liquidity risk and bank portfolio management in a financial system without deposit insurance: Empirical evidence from prewar Japan. International Review of Economics and Finance, 19(3), 392-406.

Stewart, C., Matousek, R., \& Nguyen, T. N. (2016). Efficiency in the Vietnamese banking system: A DEA double bootstrap approach. Research in International Business and Finance, 36, 96-111.

VanHoose, D. (2007). Theories of bank behavior under capital regulation. Journal of Banking \& Finance, 31(12), 3680-3697.

Vo, X. V. (2016). Finance in Vietnam - An overview. Afro-Asian Journal of Finance and Accounting, 6(3), 202-209.

Vo, X. V. (2018a). Bank lending behavior in emerging markets. Finance Research Letters, 2, 129134.

Vo, X. V. (2018b). Do firms with state ownership in transitional economies take more risk? Evidence from Vietnam. Research in International Business and Finance, 46, 251-256. 